\title{
Impact of 3D cell culture on bone regeneration potential of mesenchymal stromal cells
}

\author{
Mesude Bicer ${ }^{1}$, Graeme S. Cottrell ${ }^{2}$ and Darius Widera ${ }^{1 *}$ (D)
}

\begin{abstract}
As populations age across the world, osteoporosis and osteoporosis-related fractures are becoming the most prevalent degenerative bone diseases. More than 75 million patients suffer from osteoporosis in the USA, the EU and Japan. Furthermore, it is anticipated that the number of patients affected by osteoporosis will increase by a third by 2050. Although conventional therapies including bisphosphonates, calcitonin and oestrogen-like drugs can be used to treat degenerative diseases of the bone, they are often associated with serious side effects including the development of oesophageal cancer, ocular inflammation, severe musculoskeletal pain and osteonecrosis of the jaw.

The use of autologous mesenchymal stromal cells/mesenchymal stem cells (MSCs) is a possible alternative therapeutic approach to tackle osteoporosis while overcoming the limitations of traditional treatment options. However, osteoporosis can cause a decrease in the numbers of MSCs, induce their senescence and lower their osteogenic differentiation potential.

Three-dimensional (3D) cell culture is an emerging technology that allows a more physiological expansion and differentiation of stem cells compared to cultivation on conventional flat systems.

This review will discuss current understanding of the effects of different 3D cell culture systems on proliferation, viability and osteogenic differentiation, as well as on the immunomodulatory and anti-inflammatory potential of MSCs.
\end{abstract}

Keywords: 3D scaffolds, Osteogenic differentiation, Mesenchymal stem cells, Osteoregeneration, Stem cell therapy, Bone tissue engineering

\section{Background}

Bone remodelling is a continuous cycle of degeneration and regeneration, involving osteoblasts (bone-forming cells) and osteoclasts (cells that absorb bone tissue) (Fig. 1). If the balance between bone formation and bone resorption is lost, the bone becomes vulnerable to osteoporosis [1].

\footnotetext{
* Correspondence: d.widera@reading.ac.uk

${ }^{1}$ Stem Cell Biology and Regenerative Medicine Group, Reading School of Pharmacy, University of Reading, PO Box 226, Whiteknights, Reading RG6 6AP, UK

Full list of author information is available at the end of the article
}

Osteoporosis is characterised by low bone mass which is strongly associated with increased bone resorption combined with reduced bone regeneration [2] and mostly affects postmenopausal women [3]. In the context of bone homeostasis, oestrogen regulates osteoblast survival and suppresses cellular apoptosis [4]. The onset and development of osteoporosis are related to the life span of osteoblasts. Oestrogen plays an important role in the reduction of apoptotic gene expression in osteoblasts [5] with nuclear oestrogen receptors and androgen receptors being directly involved in the process of bone

C C The Author(s). 2021 Open Access This article is licensed under a Creative Commons Attribution 4.0 International License, which permits use, sharing, adaptation, distribution and reproduction in any medium or format, as long as you give appropriate credit to the original author(s) and the source, provide a link to the Creative Commons licence, and indicate if changes were made. The images or other third party material in this article are included in the article's Creative Commons licence, unless indicated otherwise in a credit line to the material. If material is not included in the article's Creative Commons licence and your intended use is not permitted by statutory regulation or exceeds the permitted use, you will need to obtain permission directly from the copyright holder. To view a copy of this licence, visit http://creativecommons.org/licenses/by/4.0/ The Creative Commons Public Domain Dedication waiver (http://creativecommons.org/publicdomain/zero/1.0/) applies to the data made available in this article, unless otherwise stated in a credit line to the data. 


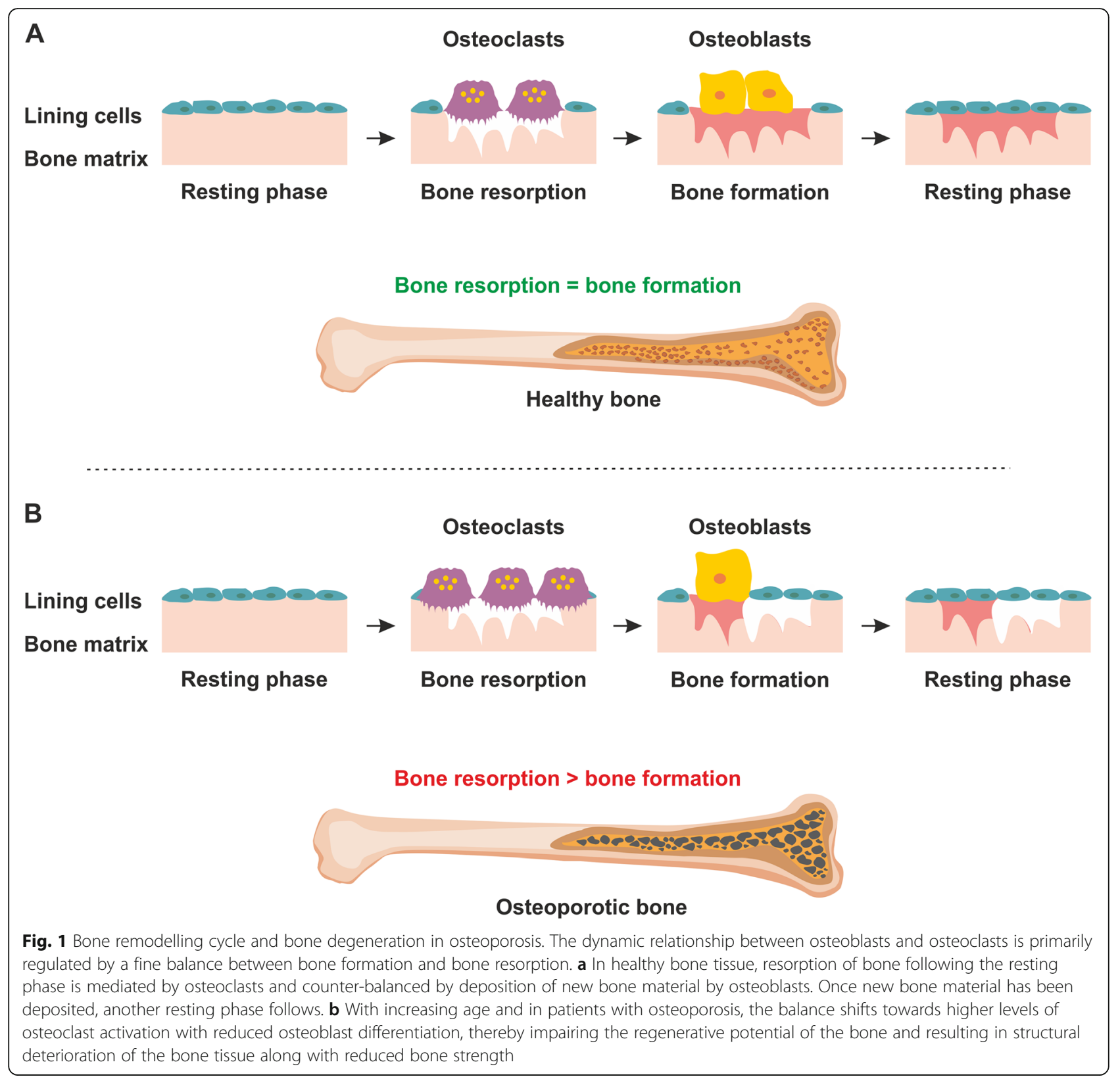

remodelling and in modulation of the levels of interleukin-6 (IL-6) [6].

In addition to its impact on osteoblasts, oestrogen has two potential roles in regulating osteoclasts. Briefly, it decreases osteoclast cell differentiation by suppressing receptor activator of nuclear factor kappa-B ligand/ macrophage colony-stimulating factor (RANKL/M-CSF) signalling [7] and indirectly blocks the production of the bone-resorbing cytokines IL-1 $\beta$, IL-6, tumour necrosis factor- $\alpha$ (TNF- $\alpha)$, M-CSF and prostaglandins [8]. In addition, it inhibits bone resorption by directly inducing apoptosis of osteoclasts [9].

In addition to oestrogen, inflammatory signalling and the activity of the immune system are also involved in bone and regeneration and degeneration. In the acute phase after injury or at the onset of osteoporosis, local levels of pro-inflammatory cytokines in the bone tissue rise causing immune cell infiltration, macrophage polarisation towards the pro-inflammatory M1 phenotype and release of chemokines. This in turn induces migration of the cellular ancestors of osteoblasts, MSCs, from their niche to the bone and has a positive influence on bone regeneration $[10,11]$. However, if the inflammation becomes chronic as in osteoporosis, this promotes strong and persistent activity of immune cells interfering with bone regeneration [12].

Given this complex nature of molecular and cellular mechanisms involved in osteoporosis, development of 
therapeutic interventions is challenging and represents a major and unmet clinical need.

\section{Current therapeutic options and their limitations}

Prior to 2002, one of the most common therapies prescribed for osteoporosis was hormone replacement therapy (HRT). In addition to prescribing HRT for female patients with osteoporosis, postmenopausal women were advised to take oestrogen to prevent a loss of bone density [13]. In 2002, however, it was reported that HRT increases the risk of breast cancer and heart disease. As a result, less patients are now prescribed HRT [14].

In recent years, alternative approaches to treat bone degeneration have been developed. These range from systemic pharmacological approaches to surgical procedures.

Currently, the main therapeutic agents for treating osteoporosis include anti-resorptives such as HRT, selective oestrogen-receptor modulators (SERMs) and anti-RANKL antibodies. An ideal pharmacological intervention treating bone loss should suppress osteoclastic activity and enhance osteoblast-mediated bone formation [13]. A humanised monoclonal antibody (denosumab) has recently been developed that inhibits osteoclastic differentiation by preventing RANKL from binding to its receptor [13]. Long-term administration of denosumab has been shown to have positive effects not only on the prevention of fragility fracture, but also on the amelioration of joint damage in osteoporotic patients [15]. However, treatment with denosumab is linked to an increased risk of hypocalcaemia and osteonecrosis of the jaw [16].

As an alternative pharmacological treatment option, parathyroid hormone therapy (PTH) has been explored for treating severe osteoporosis in men and postmenopausal women with osteoporosis. A systematic review on the PTH for the treatment of osteoporosis revealed that PTH increases bone mineral density and reduces the risk of fractures by decreasing osteoblast apoptosis. It also enhances differentiation of osteoblasts from preosteoblasts, thereby inducing new bone deposition. Despite its high potential, PTH therapy has its drawbacks including side effects like headaches, injection-site tenderness and nausea in osteoporotic patients [17].

A sclerostin (SOST) antibody and interferon $\gamma($ IFN $\gamma$ ) also have therapeutic potential in treatment of osteoporosis [13]. The SOST antibody modulates osteoblastic activity and bone formation, by inhibiting Wnt/ $\beta$-catenin signalling [18]. IFN $\gamma$ can be an effective anabolic treatment for osteoporosis as in the bone micro-environment it is secreted by MSCs to promote osteogenic differentiation [19]. However, there are risks associated with local interferon therapy for bone loss, such as gastrointestinal tract symptoms [19]. Bisphosphonates (BPs) are commonly used for the treatment of osteoporosis, as they have the potential to suppress osteoclast formation $[20,21]$ and can break the osteoblast/osteoclast coupling. However, a drawback of BPs is that they can cause osteonecrosis of the jaw [22].

In addition to these pharmacological options, osteoporosis treatment can involve surgical procedures including autologous bone grafts, allograft implantations and free fibula vascularised grafts [23]. Even though autologous bone grafting is currently seen as the gold standard, this technique still has drawbacks in terms of a high risk of morbidity and intervention-induced inflammation [24].

Thus, safe and predictable therapies for osteoporosis are an unmet clinical need. In this respect, stem cell therapy for osteoporosis is a novel approach proposed to increase bone formation.

\section{MSCs as a potential stem cell therapy for bone degeneration}

In light of the limitations of conventional therapies, the use of stem cells has been explored in the context of bone healing. Due to their wide availability, minimally invasive isolation procedures and their regenerative potential, MSCs are considered the most suitable stem cell type to be used in treatment of osteoporosis [25].

MSCs are fibroblast-like cells able to differentiate into mesenchymal derivatives including bone, fat and cartilage cells (see [26] for review). They can be readily obtained from various adult tissues including the bone marrow, adipose tissue and peripheral blood. Their high availability and low-risk profile made MSCs a promising stem cell type for clinical exploitation [27]. As of July 2020 , over 1100 clinical trials have been registered on the ClinicalTrials.gov database with a wide indication profile including diabetes, cardiovascular disorders and musculoskeletal symptoms.

As cellular ancestors of osteoblasts, MSCs can contribute to bone regeneration either directly by integrating and differentiating into bone tissue or by indirect stimulation of endogenous regeneration processes.

Direct differentiation of rat MSCs into the osteogenic lineage was first reported by Friedenstein et al. as early as 1974 [28]. Following this discovery, MSCs from numerous species and origins have been demonstrated to undergo differentiation into osteogenic cells. Consequently, in their position paper, The International Society for Cellular Therapy Position Statement defined the ability to give rise to bone cells in vitro as one of the minimal criteria for defining MSCs [29]. In addition to in vitro differentiation, even more stringent evidence for osteogenic potential of MSCs has been provided by several in vivo studies in different small and large animal models including rats [30], sheep [31] and pigs [32]. 
Cumulatively, these promising in vitro and in vivo results motivated several clinical trials designed to assess the feasibility, safety and efficacy of MSCs in oral bone regeneration [33-35]. Although several individual trials suggested that transplantation of MSCs is safe and associated with improved oral bone regeneration, a more recent meta-analysis did not reveal a significant increase in vital bone mass [36]. This can be at least partly attributed to the fact that in contrast to early pre-clinical studies claiming that a high number of transplanted MSCs undergo differentiation to regenerate the bone, very few regenerative cells survive following transplantation [37]. This has been eloquently demonstrated in a recent study, where human MSCs have been transplanted into large segmental bone defects in rats [38]. Although a significantly improved healing of large segmental bone defects has been demonstrated, tracking experiments failed to conclusively demonstrate long-term survival and differentiation of MSCs in the regenerated bone.

According to the database ClinicalTrials.org, no clinical trials utilising MSC transplantation as a therapeutic option to treat osteoporosis or osteoporotic fractures have been completed as of July 2020. However, MSCs have been shown to prevent progression of osteoporosis in a mouse model of age-related osteoporosis [39]. Briefly, the authors demonstrated that a single dose of MSCs increased the bone turnover rate and reversed the age-associated reduction of bone formation compared to sham controls. These promising results indicate that MSCs may have relevance in the treatment of osteoporosis in humans.

In addition to differentiation and functional integration, MSCs are widely believed to contribute to regeneration via paracrine factors, acting as 'bystander cells' that modulate endogenous regeneration (Fig. 2). Indeed, in light of the general consensus that the therapeutic benefit of MSCs is paracrine, Arnold I. Caplan, who first coined the term 'mesenchymal stem cells', recommends referring to this cell type as 'medicinal signalling cells' [40]. Current understanding of these 'bystander effects' mediated by the secretome of MSCs is that they include two main factors-immunomodulation and reduction of inflammation. In the context of immunomodulation, MSCs and their secretome can affect a wide variety of immune cells including but not limited to macrophages, dendritic cells, $\mathrm{T}$ cells, B cells and natural killer cells (reviewed in [41]), resulting in local immunosuppression.

Notably, the anti-inflammatory action of the MSC secretome is not limited to immune cells as it can reduce the levels of pro-inflammatory markers in other tissues including cartilage [42] and muscle tissue [43]. In addition, "bystander effects' on the surrounding tissue include paracrine modulation of angiogenesis, anti-apoptosis and chemoattraction, as well as stimulation of resident cell proliferation [44].

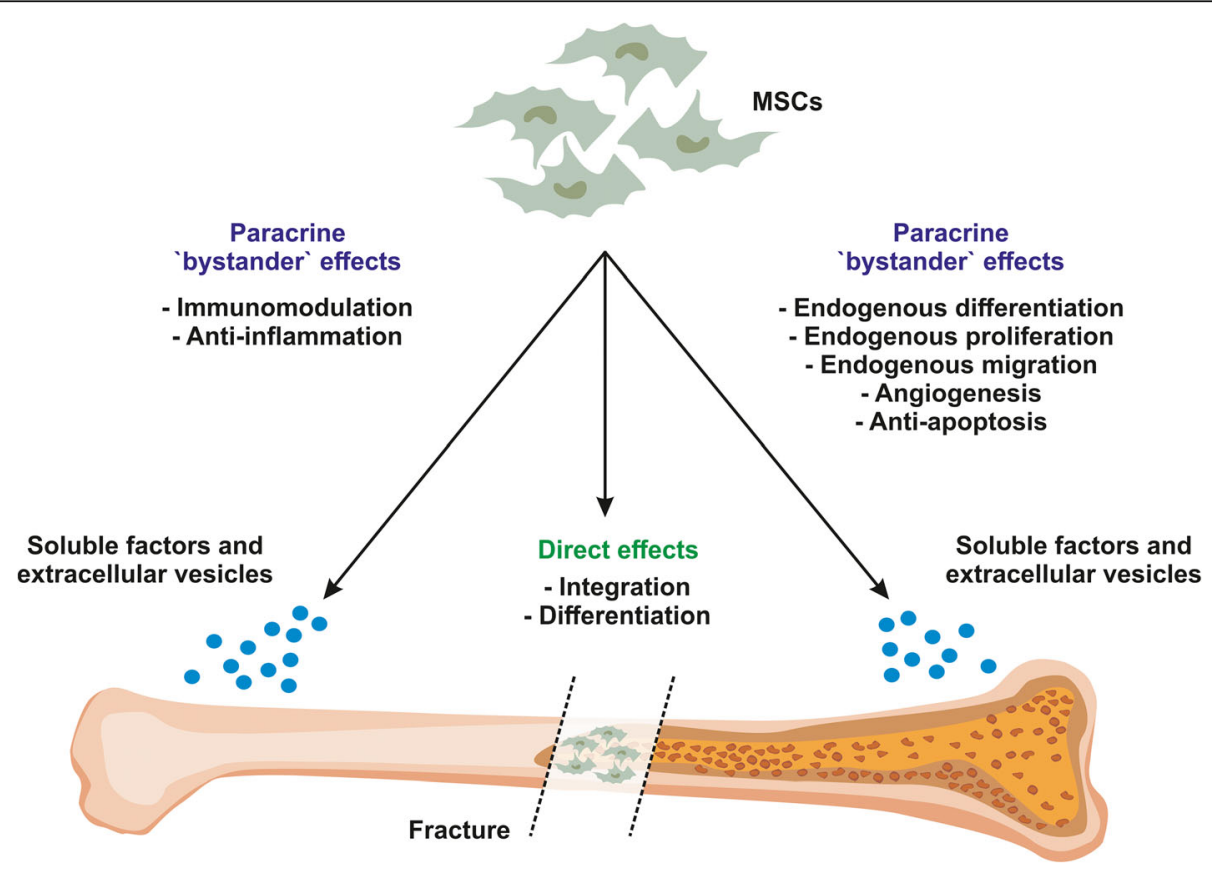

Fig. 2 Contribution of MSCs to regeneration in bone fractures. In the acute phase after a bone fracture, resident or transplanted MSCs release a magnitude of paracrine factors which in turn attract immune cells and additional MSCs to the side if the injury. Paracrine actions of MSCs also include modulation of endogenous cell differentiation, proliferation and angiogenesis. In addition, they are able to integrate and undergo osteogenic differentiation thereby replacing lost bone material. Finally, in the late stage of bone regeneration, MSCs contribute to regeneration by releasing soluble and extracellular vesicle embedded immunomodulatory and anti-inflammatory factors including proteins and miRNAs 
The paracrine factors responsible for the effects introduced above are soluble factors including cytokines, growth factors and chemokines in addition to proteins and miRNAs embedded within extracellular vesicles (EVs) (reviewed in [45]). Indeed, multiple pre-clinical and clinical reports provided evidence that MSCs exert at least part of their therapeutic functions via EVs such as exosomes and microvesicles [43, 46-49]. EVs are secreted by almost all cell types under physiological and pathological situations, are anti-inflammatory and immunomodulatory and have a specific combination of proteins, lipids and microRNAs as their cargo $[50,51]$.

Despite the high clinical potential, MSC-based approaches to tackle osteoporosis are limited by the fact that osteoporosis has a negative impact on the number and osteogenic differentiation potential of MSCs [5254]. This can at least partly be attributed to a shift of osteoporotic MSCs towards an adipogenic fate, which is believed to interfere with new bone formation in osteoporosis $[55,56]$.

An additional factor playing a role in the lower osteogenic potential of osteoporotic MSCs is that in senile osteoporosis, MSCs undergo cellular senescence resulting in a growth arrest [57].

Finally, it has been demonstrated that MSCs isolated from mice with experimental osteoporosis have a significantly lower anti-inflammatory potential and lower expression levels of immunomodulatory cytokines including TGF- $\beta$ and IL-10 compared to MSCs derived from control mice [58].

Thus, increasing the viability, as well as the proliferative and osteogenic differentiation capacity, while retaining the anti-inflammatory and immunomodulatory potential of MSCs are still essential steps required to deliver a successful and reliable autologous stem cell-based therapy for osteoporosis.

\section{Impact of 3D cell culture on bone regeneration- relevant properties of MSCs}

Traditional, two-dimensional (2D) cell culture on flat plastic or glass surfaces is still widely used in regenerative medicine and basic stem cell research. However, removing stem cells from their endogenous 3D niche results in unnatural polarity, changes in growth kinetics and last but not least, an altered differentiation potential. In this context, 2D culture of MSCs is known to result in a loss of multipotency and premature cellular senescence [59]. Moreover, 2D cell culture conditions have been linked to accumulation of chromosomal aberrations within the MSC genome [60, 61].

To address these problems, MSCs have been subjected to a wide range of $3 \mathrm{D}$ cell culture methods including cultivation as scaffold-free spheroids [62, 63] (reviewed in [64]) and different hydrogel scaffolds including alginates [65], collagen [66], Matrigel [67] and various formulations of cellulose [68-71].

In the following sections, we will summarise current knowledge on the impact of 3D cell culture on fundamental properties of MSCs that are pivotal in bone regeneration. To directly assess the effects of 3D cell culture on MSCs, the following sections only cover studies that have explicitly used 2D controls. Moreover, reports using less than two independent methods to determine the cell fate have been excluded.

\section{Viability and proliferation}

3D cell culture has been widely used in cancer research. Notably, the impact of 3D cultivation on cell viability and proliferation has been shown to be cell type and technique dependent. While some studies reported an increase in viability and proliferation compared to the respective $3 \mathrm{D}$ controls, others observed opposite effects (reviewed in [72]). This can be, at least partly, attributed to the nature of the 3D cell culture method. Since osteoporosis and ageing in general negatively affect viability and proliferation of MSCs, assessing the impact of 3D cell culture technology on these parameters is important for developing successful therapeutic strategies.

Briefly, spheroid cell culture has often been associated with decreases in cellular proliferation and viability, while 3D hydrogels can have an equal or superior performance compared to 2D cultures (reviewed in [73]). Contrary to reports on the impact of spheroid culture on other cell types including cancer cells and neural crest-derived stem cells indicating negative effects on cell proliferation and viability [74], the consequences of cultivation of MSCs as spheroids are still controversial. While some studies suggested an increase in cell viability and proliferation of MSCs within the spheroids [75, 76], others reported no effects [77] or a reduced cell proliferation [78-80]. This could be attributed to a nonhomogenous nutrient and oxygen supply and impaired waste product diffusion in the core if a critical sphere size has been reached (reviewed in [64]).

Similar to the contradicting reports on the impact of spheroid cultures on cell proliferation and viability, the effects of 3D culture of MSCs on scaffolds and within hydrogels are complex. While some 3D scaffolds including gelatine, poly lactic-co-glycolic acid and chitosan do not seem to affect viability and the proliferation of MSCs [81], other substrates have been reported to change these properties. In this context, collagen seems to have different effects depending on its preparation and the source of MSCs. Lo and colleagues did not observe significant changes in cell viability and proliferation of collagen-embedded human MSCs [81], while rat bone marrow MSCs (BM-MSCs) have been reported to increase their proliferation in the same scaffold [82]. Other 
reports also suggest that small differences in the scaffold composition and preparation technique can be decisive for the biological outcome.

In 2013, a study by Rampichová et al. suggested that 3D cultivation of minipig MSCs in electrospun 3D polycaprolactone increases both, their proliferation and viability [83].

In contrast to these findings, 3D printed polycaprolactone/tricalcium phosphate did not affect the viability of human adipose tissue-derived MSCs (AD-MSCs) and BM-MSCs [84]. Interestingly, Brennan and colleagues demonstrated that sprayed micro-fibre polycaprolactone scaffolds increase human BM-MSC proliferation, while electrospun variants of the same scaffold decreased proliferation compared to the 2D controls [85]. This provides further evidence that small differences in the nature of the scaffold can dictate very different cell fates. In general accordance with this hypothesis, woven biodegradable composite fibres from poly (L-lactic acid) substituted with hydroxyapatite had an overall positive effect on BM-MSC viability, while the same substrate alone reduced it [86]. Conversely, Nguyen and colleagues reported that electrospun scaffolds significantly reduced proliferation of human MSCs as early as 7 days after seeding on nanofibrous scaffolds composed of poly (Llactic acid) and type I collagen [87].

In our lab, we have studied the effects of 3D nanofibrillar cellulose on human MSCs derived from various tissue types. In our hands, low concentrations $(0.2 \%)$ of nanofibrillar cellulose did not negatively affect the proliferation of BM-MSCs, AD-MSCs and palatal MSCs, whereas higher concentrations $(0.5 \%)$ significantly reduced cellular viability and proliferation compared to $2 \mathrm{D}$ controls [70]. In contrast, a follow-up study showed that an anionic form of nanofibrillar cellulose significantly increased the viability of human AD-MSCs [71]. Similarly, Yin and colleagues recently reported that 3D cultivation of AD-MSCs in a nanofibrous polysaccharide hydrogel increases their proliferation and viability [88].

Overall, the effects of 3D seem to rely on multiple factors including but not limited to the nature of the scaffold, its preparation and the origin of the MSCs.

\section{Osteogenic differentiation}

In addition to influencing the viability and proliferation of MSCs, multiple reports suggest that 3D cultivation might have an impact on their osteogenic differentiation. In contrast to the controversial impact of MSC viability, $3 \mathrm{D}$ cell culture seems to increase the osteogenic differentiation compared to conventional 2D culture.

It has been demonstrated that cultivation of rat BMMSCs as spheroids resulted in an increased osteogenic potential compared to 2D controls [67]. This has been evidenced by a higher expression of Osterix, increased
ALP activity and higher level of mineralisation in vitro. Similarly, scaffold-free 3D spheroid culture of murine BM-MSCs resulted in a 5-fold higher mineralisation compared to osteogenic differentiation of $2 \mathrm{D}$ cultures [79].

A 2008 report provided evidence that 3D nanofibrillar scaffolds prepared from rat tail collagen increased the expression of osteogenic markers including type I collagen, osteopontin (OPN) and osteonectin in human ADMSCs compared to differentiation conducted in 2D. Although Alizarin Red S staining in this report suggested that calcification could also be increased, the significance of the data was not assessed [89]. Similar effects on the expression levels of osteocalcin, OCN and OPN in rat BM-MSCs were observed if purified collagen was used to create a 3D scaffold [82]. Notably, von Kossa staining revealed statistically significant increase of calcification. In 2012, Nguyen and colleagues used a blended scaffold composed of collagen and electrospun poly(L-lactic acid) to study the influence of 3D cell culture on the differentiation of human MSCs of undefined origin. In their study, they showed that differentiation in 3D significantly increases expression of OCN and OPN and augments the levels of calcification compared to cells differentiated in 2D [87]. Moreover, use of pure poly (Llactic acid) scaffolds as a substrate showed similar increases in expression of pro-osteogenic markers compared to human BM-MSCs differentiated in 2D [86]. This was accompanied by a significant increase of $\mathrm{Ca}^{2+}$ deposition demonstrated via von Kossa and Alizarin Red $S$ staining.

In addition to collagen, poly(L-lactic acid) and blends of these materials, Matrigel, a hydrogel mainly composed of type IV collagens, entactin, perlecan and laminin has been shown to increase the osteogenic differentiation potential compared to $2 \mathrm{D}$ cell culture. If differentiated within a Matrigel scaffold, human BM-MSCs showed higher activity of alkaline phosphatase (an early marker of osteogenesis) compared to the 2D counterparts [90]. In addition, Alizarin Red S staining revealed higher $\mathrm{Ca}^{2+}$ deposition in cells differentiated in 3D.

As alternative scaffolds, different polycaprolactonebased substrates have been explored in combination with MSCs. An elastic 3D poly ( $\varepsilon$-caprolactone) has been shown to increase the expression of bone sialoprotein and OCN in minipig BM-MSCs subjected to differentiation in 3D [83]. In accordance with this report, polycaprolactone-tricalcium phosphate scaffolds and jet sprayed micro-fibre polycaprolactone scaffolds have shown similar osteoinductive effects in human foetal and adult BM-MSCs $[85,91]$. There are also reports on increased osteogenic differentiation of AD-MSCs and BM-MSCs in 3D vs 2D, if gelatine and blends of gelatine and alginate are used as a scaffold [81, 92]. 


\section{Cellular senescence}

Increased cellular senescence of MSCs is one of the contributing factors for poor osteogenic regeneration in osteoporosis. Although studying the impact of 3D cell culture on cellular senescence is a relatively new field, there is some evidence suggesting that propagation of cells in 3D might reduce their cellular senescence. In this context, Cheng and colleagues have clearly demonstrated that 3D cultivation of human AD-MSCs as scaffold-free spheroids prolongs their replicative lifespan and decreases their senescence compared to 2D controls [93]. However, a recent report provided evidence that the number of senescent cells within MSC spheroids increases over time [94].

In contrast, it has been reported that cultivation of human periodontal ligament fibroblasts, a cell type which is phenotypically indistinguishable from MSCs [95], in 3D methylcellulose hydrogels results in suppression of TNF- $\alpha$-induced cellular senescence and an increase in proliferation and migration [96]. In an attempt to study the stress response in human endometrial MSCs cultivated as $3 \mathrm{D}$ spheroids in comparison to conventional $2 \mathrm{D}$ culture, Domnina and colleagues exposed cells cultivated under both conditions to heat shock and treatment with $\mathrm{H}_{2} \mathrm{O}_{2}$ [97]. This study demonstrated that 2D monolayer MSCs developed premature senescence, while MSCs in 3D exhibited decreased viability without cell cycle arrest and other signs of senescence. Interestingly, subsequent analyses revealed that 3D MSCs that did not undergo apoptosis in response to heat shock-induced stress, resumed cell division and had comparable proliferation rates and cell cycle dynamics compared to the $2 \mathrm{D}$ controls. These results suggest that 3D culture can be helpful in eliminating senescent cells from MSC cultures.

Finally, a very recent comparison of cellular senescence in human adipose-derived MSCs cultivated in a monolayer and cells in a commercial polysaccharide hydrogel revealed significant reduction of senescenceassociated $\beta$-galactosidase activity in 3D. Moreover, an overall higher telomerase activity and greater telomere length was observed in MSCs in 3D. This was accompanied by a higher adipogenic and osteogenic differentiation potential [88].

Overall, this promising data suggests that 3D cultivation might reduce cellular senescence of MSCs, thereby facilitating the ability to obtain clinically relevant cell numbers in a shorter time frame.

\section{MSC secretome, immunomodulation and anti- inflammatory potential}

In addition to its direct impact on characteristics of MSCs, 3D cell culture has been suggested to modulate the regenerative potential of their secretome.
Although there is some evidence that 3D cultivation as spheroids can reduce the anti-inflammatory and immunomodulatory potential of MSCs [98], most secretomes produced by MSCs cultivated in 3D hydrogels seem to have higher anti-inflammatory and immunomodulatory properties, and an overall greater regenerative potential compared to both spheroids and conventionally cultivated cells.

Cultivation of human AD-MSCs as spheroids has been shown to increase expression of vascular endothelial growth factor (VEGF) and hepatocyte growth factor (HGF) compared to 2D, although no significant differences in the levels of fibroblast growth factor-2 (FGF-2) have been observed [93]. Moreover, human BM-MSCs cultivated as spheroids generated by the hanging drop method showed higher levels of the anti-inflammatory cytokine interleukin 24 (IL-24) [63]. Interestingly, the same study provided evidence that spheroid MSCs were more efficient in supressing LPS-induced inflammation compared to their $2 \mathrm{D}$ counterparts. In accordance with these findings, dynamic culture of human MSC spheroids in spinner flasks has been shown to result in increased levels of IL-24 secretion [99]. A more recent study provided further evidence for a change of paracrine properties of spheroid MSCs. Briefly, Sun and colleagues demonstrated that MSC spheroids secrete higher levels of VEGF [100]. In addition, spheroid cultures of MSCs have been demonstrated to produce higher levels of prostaglandin E2 that mediated polarisation of macrophages towards the anti-inflammatory M2 phenotype $[101,102]$.

In addition to spheroid cultures, a higher regenerative potential of secretomes from 3D cultivated AD-MSCs compared to $2 \mathrm{D}$ culture has been reported by Chierchia et al. [103]. In this study, MSC secretome-mediated neuroprotection of SH-SY5Y neuroblastoma cells following 6-hydroxydopamine treatment was increased if the MSCs were cultivated in bovine collagen/polyethylene glycol and collagen/low-molecular weight hyaluronic acid hydrogels. However, to date, no molecular profiling of these secretomes has been reported.

In 2018, it was also reported that 3D spheroid cultures of human BM-MSCs secreted higher levels of VEGF compared to 2D controls [62]. These findings are in line with several other reports demonstrating that 3D cultivation of AD-MSCs results in an increased secretion of multiple growth factors including HGF, VEGF, stromal cell-derived factor (SDF) and FGF-2 [75, 104, 105].

More recently, Carter and colleagues studied the wound healing potential of 2D, and 3D cultivated human BM-MSCs in vitro and ex vivo [106]. In their study, they demonstrated that 3D cell culture of MSCs on electrospun gelatine/polycaprolactone fibres increased the secretion of FGF-2, IL-6, VEGF and HGF compared to 2D 
controls. In addition, 3D cell culture significantly improved secretome-mediated corneal wound healing in a rabbit corneal organ culture system [106].

A comparative analysis of the secretomes of umbilical cord MSCs cultivated as spheroids and as adherent monolayer revealed that $3 \mathrm{D}$ cultivation significantly increases the secretion of IL-10, LIF, FGF-2, I-309, SCF and GM-CSF [107]. Moreover, this study also showed that secretome from 3D cultivated MSCs has superior regenerative and anti-inflammatory potential in an in vivo model of arthritis in adult Wister rats.

Overall, 3D cultivation is associated with increased level of secreted molecular factors that are pivotal in bone regeneration (see Table 1). Thus, the findings summarised above suggest that 3D cultivation can indeed increase the levels of bone regeneration-relevant components within the MSC secretome.

\section{Potential mechanisms instructing osteogenic potential of MSCs in 3D}

In addition to biochemical signals, mechanophysical cues including surface stiffness and presence of micro- and nanoscale pores, pillars and pits are known to heavily influence the fate of stem cells [120]. In vivo, many of these cues are provided by the extracellular matrix (ECM) and include matrix stiffness and presence of pores, pillars and pit-like structures at microscale and nanoscale (macro- and nanotopography). The stiffness of the ECM in the human body ranges from $0.1-1 \mathrm{kPa}$ in the brain to $25-40 \mathrm{kPa}$ in osteoids (unmineralised, organic portion of the bone matrix that develops prior to the maturation of bone tissue) [121]. In contrast, conventional cell culture plastic material is very rigid with a stiffness of 1-10 GPa [122]. Indeed, MSCs have been described to be highly sensitive to substrate stiffness. However, reports on the optimal osteoinductive stiffness are conflicting. While Hwang et al. reported a stiffness of $4.47 \mathrm{kPa}$ as osteoinductive [95], a much higher Young's modulus ranging from 62 to $800 \mathrm{kPa}$ has been suggested in studies from other laboratories [94, 96]. Importantly, although stiffness can be manipulated in $2 \mathrm{D}$ to study
MSC differentiation [121, 123], it is important to consider that in vivo MSCs are exposed to the mechanophysical cues in all three dimensions of the surrounding niche. Therefore, spheroid cultures and hydrogels surrounding the cells might provide stronger inductive cues compared to the more artificial environment in 2D.

In addition to the stiffness, both macro- and nanotopography of the stem cell niche play an inductive role in cell differentiation.

In this context, it has been established that nanopores with a diameter of $30 \mathrm{~nm}$ within elastic (collagen) and rigid 2D surfaces (titanium) are strong osteoinductive cues for adult stem cells [124-126]. In addition, 2D micropores of 60 and $550 \mu \mathrm{m}$ have been reported to have a positive impact on osteogenic differentiation [127]. Interestingly, electron microscopic analyses of the structure of various hydrogels including different forms of nanofibrillar cellulose and fibrin have revealed a presence both nano- and micropores [70, 71, 128]. Thus, these nanoscopic and microscopic features could provide a potential explanation for the increased osteogenic potential of MSCs in 3D. Notably, differences in the nano-, micro- and macropore profiles of different scaffolds would have an impact on nutrient, oxygen and waste product diffusion and could explain the differences in viability and proliferation described earlier.

Interestingly, physical properties of scaffolds can also dictate the paracrine potential of MSCs [129] with substrates with an elasticity of $20 \mathrm{kPa}$ resulting in an increase of expression of anti-inflammatory factors compared to more elastic substrates with an elasticity of $2 \mathrm{kPa}$. In 3D and depending on the nature of the hydrogel, retention of the secreted soluble factors and EVs could also contribute to the increased osteogenic potential. Indeed, peptide-modified hyaluronic acid hydrogels have been shown to retain EVs and show beneficial therapeutic outcomes in animal models of spinal cord injury [130]. Similarly, umbilical cord MSC-derived EVs encapsulated in functional peptide hydrogels increased the retention and stability of exosomes and improved heart function in a rat myocardial infarction model

Table 1 Examples of bone homeostasis-relevant paracrine factors released by MSCs

\begin{tabular}{|c|c|c|}
\hline Target & Paracrine factors & References \\
\hline Osteogenic differentiation & TGF $\beta$, BMP-1 and miR-196a & {$[108-110]$} \\
\hline Anti-inflammation & IL-10, TGF $\beta$, TSG-6, LIF, miR-146a-5p, miR-548e-5p, let 7 family, miR-145 & {$[43,108,111-115]$} \\
\hline Immunomodulation & PGE-2, HLA-G5, HGF, iNOS, TGF $\beta$ and IL-10 & {$[108,116,117]$} \\
\hline Anti-apoptosis & VEGF, HGF, IGF-1, stanniocalcin-1, GM-CSF and TGF $\beta$ & {$[108,118]$} \\
\hline Angiogenesis & VEGF, IGF-1, PIGF, MCP-1, FGF-2 and IL-6 & [118] \\
\hline Support of growth and differentiation of stem cells & SCF, LIF, M-CSF, SDF-1 and angiopoietin-1 & {$[113,118]$} \\
\hline Chemoattraction & CCL2, 3, 4, 5, 6, 20 and 26 and $C X C L 5,11,1,2,8,10$ and 12 & {$[117,118]$} \\
\hline Anti-fibrosis & HGF, FGF-2 and adrenomedullin & {$[113,118,119]$} \\
\hline
\end{tabular}




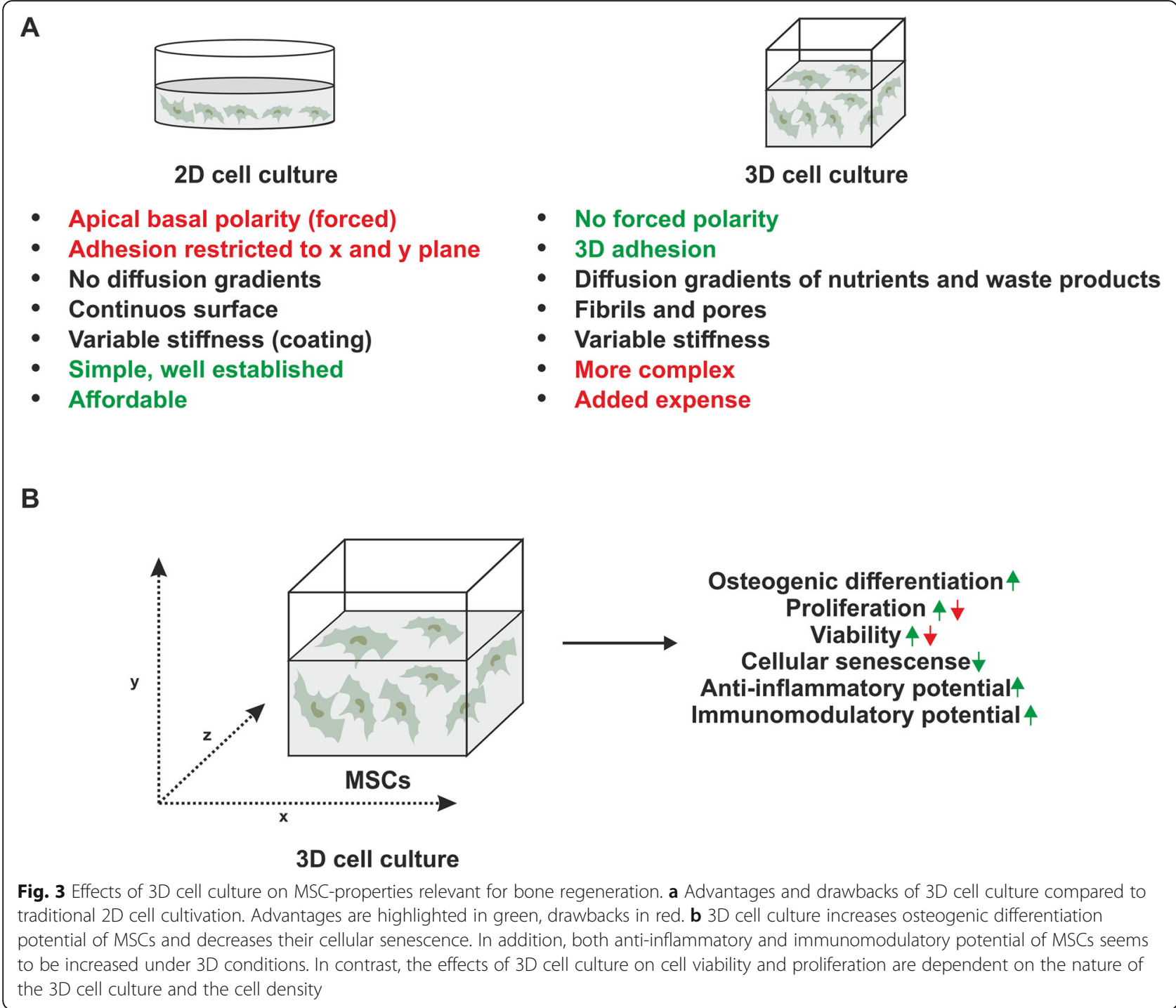

[131]. Recently, it has been demonstrated that alginate hydrogels loaded with AD-MSC-derived EVs can promote tissue regeneration in full-thickness skin wounds [132]. Finally, cellulose hydrogels have been shown to retain EVs and allow their continuous release from encapsulated cells [133]. Therefore, a potential additional mechanism increasing the osteogenic potential MSCs in 3D hydrogels could be a retention of soluble proosteogenic factors and EVs. This could exhibit both autocrine on and paracrine effects that drive osteogenesis in 3D.

\section{Conclusions}

As outlined above, the nature of the 3D scaffolds and small variations in their composition can influence the viability as well as the osteogenic and paracrine potential of MSCs (Fig. 3). Therefore, rational design of 3D cell culture parameters could further improve the performance of MCSs in bone regeneration. To achieve this, an ideal 3D scaffold should be biocompatible and osteo-conductive-inductive (reviewed in [134]). Moreover, scaffold stiffness, its topography and potential retention and release of paracrine factors need to be considered. Finally, as electrical stimulation of MSCs has been shown to enhance the osteogenic potential of MSCs [135], conductivity could also represent an important factor in designing optimal osteoinductive biomaterials.

Abbreviations

2D: Two-dimensional; 3D: Three-dimensional; AD-MSCs: Adipose tissuederived MSCs; ALP: Alkaline phosphatase; BM-MSCs: Bone marrow MSCs; BMP-1: Bone morphogenetic protein 1; BPs: Bisphosphonates; CCL: C-C motif chemokine ligand; CXCL: C-X-C motif chemokine ligand; EVs: Extracellular vesicles; FGF-2: Basic fibroblast growth factor; HGF: Hepatocyte growth factor; HLA-G5: Histocompatibility antigen, class I, G5; HM-CSF: Granulocytemacrophage colony-stimulating factor; HRT: Hormone replacement therapy;

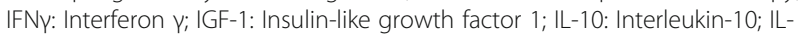




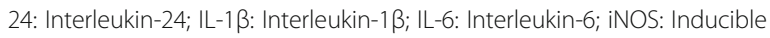
nitric oxide synthase; LIF: Leukaemia inhibitory factor; MCP-1: Monocyte chemoattractant protein-1; M-CSF: Macrophage colony-stimulating factor; MSCs: Mesenchymal stromal cells/mesenchymal stem cells; OCN: Osteocalcin; OPN: Osteopontin; PGE-2: Prostaglandin E2; PIGF: Placental growth factor; PTH: Parathyroid hormone therapy; RANKL/M-CSF: Receptor activator of nuclear factor kappa-B ligand/macrophage colony-stimulating factor; RANK L: Receptor activator of nuclear factor kappa-B ligand; SCF: Stem cell factor; SDF-1: Stromal cell-derived factor 1; SERMs: Selective oestrogen-receptor modulators; SOST: Sclerostin; TGF- $\beta$ : Tumour growth factor- $\beta$; TNF-a: Tumour necrosis factor-a; TSG-6: TNF-a-stimulated gene-6; VEGF: Vascular endothelial growth factor

\section{Acknowledgements}

Not applicable.

\section{Authors' contributions}

DW designed the concept of the review and wrote the outline. MB, GSC, and DW wrote the paper. All authors approved the final version of the manuscript.

\section{Funding}

$\mathrm{MB}$ is supported by a grant of the Ministry of National Education of the Republic of Turkey (MEB1416).

\section{Availability of data and materials}

Not applicable.

\section{Ethics approval and consent to participate}

Not applicable.

\section{Consent for publication}

Not applicable.

\section{Competing interests}

The authors declare that there are no conflicts of interest regarding the publication of this article.

\section{Author details}

${ }^{1}$ Stem Cell Biology and Regenerative Medicine Group, Reading School of Pharmacy, University of Reading, PO Box 226, Whiteknights, Reading RG6 6AP, UK. ${ }^{2}$ Cellular and Molecular Neuroscience, School of Pharmacy, University of Reading, Reading, UK

Received: 22 July 2020 Accepted: 10 December 2020

Published online: 07 January 2021

\section{References}

1. Jimi E, Hirata S, Osawa K, Terashita M, Kitamura C, Fukushima H. The current and future therapies of bone regeneration to repair bone defects. Int J Dent. 2012;2012:148261.

2. Raisz LG. Pathogenesis of osteoporosis: concepts, conflicts, and prospects. J Clin Invest. 2005;115(12):3318-25.

3. Johnell $\mathrm{O}$, Kanis JA. An estimate of the worldwide prevalence and disability associated with osteoporotic fractures. Osteoporos Int. 2006;17(12):1726-33.

4. Khosla S, Oursler MJ, Monroe DG. Estrogen and the skeleton. Trends Endocrinol Metab. 2012;23(11):576-81.

5. Bradford PG, Gerace KV, Roland RL, Chrzan BG. Estrogen regulation of apoptosis in osteoblasts. Physiol Behav. 2010;99(2):181-5.

6. Galien R, Garcia T. Estrogen receptor impairs interleukin- 6 expression by preventing protein binding on the NF-kappaB site. Nucleic Acids Res. 1997; 25(12):2424-9.

7. Mitnick MA, Grey A, Masiukiewicz U, Bartkiewicz M, Rios-Velez L, Friedman S, Xu L, Horowitz MC, Insogna K. Parathyroid hormone induces hepatic production of bioactive interleukin-6 and its soluble receptor. Am J Physiol Endocrinol Metab. 2001:280(3):E405-12.

8. Charatcharoenwitthaya N, Khosla S, Atkinson EJ, McCready LK, Riggs BL. Effect of blockade of TNF-alpha and interleukin-1 action on bone resorption in early postmenopausal women. J Bone Miner Res. 2007;22(5):724-9.

9. Kameda T, Mano H, Yuasa T, Mori Y, Miyazawa K, Shiokawa M, Nakamaru Y, Hiroi E, Hiura K, Kameda A, et al. Estrogen inhibits bone resorption by directly inducing apoptosis of the bone-resorbing osteoclasts. J Exp Med. 1997:186(4):489-95.

10. Wang L, Li Y, Chen J, Gautam SC, Zhang Z, Lu M, Chopp M. Ischemic cerebral tissue and MCP-1 enhance rat bone marrow stromal cell migration in interface culture. Exp Hematol. 2002;30(7):831-6.

11. Gibon E, Lu LY, Nathan K, Goodman SB. Inflammation, ageing, and bone regeneration. J Orthop Translat. 2017;10:28-35.

12. Mbalaviele G, Novack DV, Schett G, Teitelbaum SL. Inflammatory osteolysis: a conspiracy against bone. J Clin Invest. 2017;127(6):2030-9.

13. Demontiero O, Vidal C, Duque G. Aging and bone loss: new insights for the clinician. Ther Adv Musculoskelet Dis. 2012:4(2):61-76.

14. Isaksson E, Wang H, Sahlin L, von Schoultz B, Masironi B, von Schoultz E, Cline JM. Expression of estrogen receptors (alpha, beta) and insulin-like growth factor-l in breast tissue from surgically postmenopausal cynomolgus macaques after long-term treatment with HRT and tamoxifen. Breast. 2002; 11(4):295-300

15. Cummings SR, San Martin J, McClung MR, Siris ES, Eastell R, Reid IR, Delmas $P$, Zoog HB, Austin M, Wang A, et al. Denosumab for prevention of fractures in postmenopausal women with osteoporosis. N Engl J Med. 2009;361(8): 756-65.

16. de Sales Lima MV, Rizzato J, Gracindo Marques DV, Kitakawa D, da Silva PF, Prado Scherma A, Carvalho L. Denosumab related osteonecrosis of jaw: a case report. J Oral Maxillofac Res. 2018;9(4):e5.

17. Lou S, Lv H, Yin P, Li Z, Tang P, Wang Y. Combination therapy with parathyroid hormone analogs and antiresorptive agents for osteoporosis: a systematic review and meta-analysis of randomized controlled trials. Osteoporos Int. 2019;30(1):59-70.

18. McClung MR. Sclerostin antibodies in osteoporosis: latest evidence and therapeutic potential. Ther Adv Musculoskelet Dis. 2017;9(10):263-70.

19. Duque G, Huang DC, Dion N, Macoritto M, Rivas D, Li W, Yang XF, Li J, Lian J, Marino FT, et al. Interferon-gamma plays a role in bone formation in vivo and rescues osteoporosis in ovariectomized mice. J Bone Miner Res. 2011 26(7):1472-83.

20. Kwak HB, Kim JY, Kim KJ, Choi MK, Kim JJ, Kim KM, Shin YI, Lee MS, Kim HS, Kim JW, et al. Risedronate directly inhibits osteoclast differentiation and inflammatory bone loss. Biol Pharm Bull. 2009:32(7):1193-8.

21. Nishikawa M, Akatsu T, Katayama Y, Yasutomo Y, Kado S, Kugal N, Yamamoto M, Nagata N. Bisphosphonates act on osteoblastic cells and inhibit osteoclast formation in mouse marrow cultures. Bone. 1996;18(1):9-14.

22. Khan A. Bisphosphonate-associated osteonecrosis of the jaw. Can Fam Physician. 2008;54(7):1019-21.

23. Spin-Neto R, Marcantonio E Jr, Gotfredsen E, Wenzel A. Exploring CBCTbased DICOM files. A systematic review on the properties of images used to evaluate maxillofacial bone grafts. J Digit Imaging. 2011;24(6):959-66.

24. Pape HC, Evans A, Kobbe P. Autologous bone graft: properties and techniques. J Orthop Trauma. 2010;24(Suppl 1):S36-40.

25. Macias I, Alcorta-Sevillano N, Rodriguez Cl, Infante A: Osteoporosis and the potential of cell-based therapeutic strategies. Int J Mol Sci 2020;21(5):1653. https://doi.org/10.3390/ijms21051653.

26. Andrzejewska A, Lukomska B, Janowski M. Concise review: mesenchymal stem cells: from roots to boost. Stem Cells. 2019;37(7):855-64.

27. Lalu MM, Mclntyre L, Pugliese C, Fergusson D, Winston BW, Marshall JC, Granton J, Stewart DJ, Canadian Critical Care Trials G. Safety of cell therapy with mesenchymal stromal cells (SafeCell): a systematic review and metaanalysis of clinical trials. Plos One. 2012;7(10):e47559.

28. Friedenstein AJ, Chailakhyan RK, Latsinik NV, Panasyuk AF, Keiliss-Borok IV. Stromal cells responsible for transferring the microenvironment of the hemopoietic tissues. Cloning in vitro and retransplantation in vivo. Transplantation. 1974;17(4):331-40.

29. Dominici M, Le Blanc K, Mueller I, Slaper-Cortenbach I, Marini F, Krause D, Deans R, Keating A, Prockop D, Horwitz E. Minimal criteria for defining multipotent mesenchymal stromal cells. The International Society for Cellular Therapy position statement. Cytotherapy. 2006;8(4):315-7.

30. Kotobuki N, Katsube $Y$, Katou Y, Tadokoro M, Hirose M, Ohgushi H. In vivo survival and osteogenic differentiation of allogeneic rat bone marrow mesenchymal stem cells (MSCs). Cell Transplant. 2008;17(6):705-12.

31. Shang Q, Wang Z, Liu W, Shi Y, Cui L, Cao Y. Tissue-engineered bone repair of sheep cranial defects with autologous bone marrow stromal cells. J Craniofac Surg. 2001;12(6):586-93 discussion 594-585.

32. Stockmann P, Park J, von Wilmowsky C, Nkenke E, Felszeghy E, Dehner JF, Schmitt C, Tudor C, Schlegel KA. Guided bone regeneration in pig calvarial 
bone defects using autologous mesenchymal stem/progenitor cells - a comparison of different tissue sources. J Craniomaxillofac Surg. 2012;40(4): 310-20.

33. Rickert D, Sauerbier S, Nagursky H, Menne D, Vissink A, Raghoebar GM Maxillary sinus floor elevation with bovine bone mineral combined with either autogenous bone or autogenous stem cells: a prospective randomized clinical trial. Clin Oral Implants Res. 2011;22(3):251-8.

34. Kaigler D, Pagni G, Park CH, Braun TM, Holman LA, Yi E, Tarle SA, Bartel RL, Giannobile W. Stem cell therapy for craniofacial bone regeneration: a randomized, controlled feasibility trial. Cell Transplant. 2013;22(5):767-77.

35. Sauerbier S, Stricker A, Kuschnierz J, Buhler F, Oshima T, Xavier SP, Schmelzeisen R, Gutwald R. In vivo comparison of hard tissue regeneration with human mesenchymal stem cells processed with either the FICOLL method or the BMAC method. Tissue Eng Part C Methods. 2010;16(2):21523.

36. Padial-Molina M, O'Valle F, Lanis A, Mesa F, Dohan Ehrenfest DM, Wang HL, Galindo-Moreno P. Clinical application of mesenchymal stem cells and novel supportive therapies for oral bone regeneration. Biomed Res Int. 2015; 2015:341327.

37. Grayson WL, Bunnell BA, Martin E, Frazier T, Hung BP, Gimble JM. Stromal cells and stem cells in clinical bone regeneration. Nat Rev Endocrinol. 2015; 11(3):140-50.

38. Dupont KM, Sharma K, Stevens HY, Boerckel JD, Garcia AJ, Guldberg RE. Human stem cell delivery for treatment of large segmental bone defects. Proc Natl Acad Sci U S A. 2010;107(8):3305-10.

39. Kiernan J, Hu S, Grynpas MD, Davies JE, Stanford WL. Systemic mesenchymal stromal cell transplantation prevents functional bone loss in a mouse model of age-related osteoporosis. Stem Cells Transl Med. 2016;5(5): 683-93.

40. Caplan Al. Medicinal signalling cells: they work, so use them. Nature. 2019; 566(7742):39.

41. Weiss ARR, Dahlke MH. Immunomodulation by mesenchymal stem cells (MSCs): mechanisms of action of living, apoptotic, and dead MSCs. Front Immunol. 2019;10:1191

42. van Buul GM, Villafuertes E, Bos PK, Waarsing JH, Kops N, Narcisi R, Weinans $H$, Verhaar JA, Bernsen MR, van Osch GJ. Mesenchymal stem cells secrete factors that inhibit inflammatory processes in short-term osteoarthritic synovium and cartilage explant culture. Osteoarthr Cartil. 2012;20(10):118696.

43. Mitchell R, Mellows B, Sheard J, Antonioli M, Kretz O, Chambers D, Zeuner MT, Tomkins JE, Denecke B, Musante L, et al. Secretome of adipose-derived mesenchymal stem cells promotes skeletal muscle regeneration through synergistic action of extracellular vesicle cargo and soluble proteins. Stem Cell Res Ther. 2019;10(1):116.

44. Caplan Al. Mesenchymal stem cells: time to change the name! Stem Cells Transl Med. 2017;6(6):1445-51.

45. Eleuteri S, Fierabracci A: Insights into the secretome of mesenchymal stem cells and its potential applications. Int J Mol Sci 2019;20(18):4597. https://doi. org/10.3390/ijms20184597.

46. Bruno S, Grange C, Deregibus MC, Calogero RA, Saviozzi S, Collino F, Morando L, Busca A, Falda M, Bussolati B, et al. Mesenchymal stem cellderived microvesicles protect against acute tubular injury. J Am Soc Nephrol. 2009:20(5):1053-67.

47. Lai RC, Arslan F, Lee MM, Sze NS, Choo A, Chen TS, Salto-Tellez M, Timmers $L$, Lee CN, El Oakley RM, et al. Exosome secreted by MSC reduces myocardial ischemia/reperfusion injury. Stem Cell Res. 2010;4(3):214-22.

48. Doeppner TR, Herz J, Gorgens A, Schlechter J, Ludwig AK, Radtke S, de Miroschedji K, Horn PA, Giebel B, Hermann DM. Extracellular vesicles improve post-stroke neuroregeneration and prevent postischemic immunosuppression. Stem Cells Transl Med. 2015:4(10):1131-43.

49. Kordelas L, Rebmann V, Ludwig AK, Radtke S, Ruesing J, Doeppner TR, Epple M, Horn PA, Beelen DW, Giebel B. MSC-derived exosomes: a novel tool to treat therapy-refractory graft-versus-host disease. Leukemia. 2014;28(4):970-3.

50. Yanez-Mo M, Siljander PR, Andreu Z, Zavec AB, Borras FE, Buzas El, Buzas K, Casal E, Cappello F, Carvalho J, et al. Biological properties of extracellular vesicles and their physiological functions. J Extracell Vesicles. 2015;4:27066

51. Raposo G, Stoorvogel W. Extracellular vesicles: exosomes, microvesicles, and friends. J Cell Biol. 2013;200(4):373-83.

52. Saito A, Nagaishi K, Iba K, Mizue Y, Chikenji T, Otani M, Nakano M, Oyama K, Yamashita T, Fujimiya M. Umbilical cord extracts improve osteoporotic abnormalities of bone marrow-derived mesenchymal stem cells and promote their therapeutic effects on ovariectomised rats. Sci Rep. 2018;8(1):1161.

53. Wang Q, Zhao B, Li C, Rong JS, Tao SQ, Tao TZ. Decreased proliferation ability and differentiation potential of mesenchymal stem cells of osteoporosis rat. Asian Pac J Trop Med. 2014;7(5):358-63.

54. Tan J, Xu X, Tong Z, Lin J, Yu Q, Lin Y, Kuang W. Decreased osteogenesis of adult mesenchymal stem cells by reactive oxygen species under cyclic stretch: a possible mechanism of age related osteoporosis. Bone Res. 2015;3: 15003.

55. Jing $H$, Liao $L$, An $Y$, Su $X$, Liu S, Shuai $Y$, Zhang $X$, Jin $Y$. Suppression of EZH2 prevents the shift of osteoporotic MSC fate to adipocyte and enhances bone formation during osteoporosis. Mol Ther. 2016;24(2): 217-29.

56. Shen GS, Zhou HB, Zhang H, Chen B, Liu ZP, Yuan Y, Zhou XZ, Xu YJ. The GDF11-FTO-PPARgamma axis controls the shift of osteoporotic MSC fate to adipocyte and inhibits bone formation during osteoporosis. Biochim Biophys Acta Mol basis Dis. 2018;1864(12):3644-54.

57. Qadir A, Liang S, Wu Z, Chen Z, Hu L, Qian A: Senile osteoporosis: the involvement of differentiation and senescence of bone marrow stromal cells. Int J Mol Sci 2020;21(1):349. https://doi.org/10.3390/ijms21010349.

58. Zheng CX, Sui BD, Liu N, Hu CH, He T, Zhang XY, Zhao P, Chen J, Xuan K, Jin $Y$. Adipose mesenchymal stem cells from osteoporotic donors preserve functionality and modulate systemic inflammatory microenvironment in osteoporotic cytotherapy. Sci Rep. 2018;8(1):5215.

59. Turinetto $V$, Vitale $E$, Giachino $C$ : Senescence in human mesenchymal stem cells: functional changes and implications in stem cell-based therapy. Int J Mol Sci 2016;17(7):1164. https://doi.org/10.3390/ijms17071164.

60. Ben-David U, Mayshar Y, Benvenisty N. Large-scale analysis reveals acquisition of lineage-specific chromosomal aberrations in human adult stem cells. Cell Stem Cell. 2011:9(2):97-102.

61. Bara JJ, Richards RG, Alini M, Stoddart MJ. Concise review: bone marrow-derived mesenchymal stem cells change phenotype following in vitro culture: implications for basic research and the clinic. Stem Cells. 2014;32(7):1713-23.

62. Redondo-Castro E, Cunningham CJ, Miller J, Brown H, Allan SM, Pinteaux E. Changes in the secretome of tri-dimensional spheroid-cultured human mesenchymal stem cells in vitro by interleukin-1 priming. Stem Cell Res Ther. 2018;9(1):11.

63. Bartosh TJ, Ylostalo JH, Mohammadipoor A, Bazhanov N, Coble K, Claypool $\mathrm{K}$, Lee $\mathrm{RH}$, Choi H, Prockop DJ. Aggregation of human mesenchymal stromal cells (MSCs) into 3D spheroids enhances their antiinflammatory properties. Proc Natl Acad Sci U S A. 2010;107(31):13724-9.

64. Cesarz Z, Tamama K. Spheroid culture of mesenchymal stem cells. Stem Cells Int. 2016:2016:9176357.

65. Ho SS, Murphy KC, Binder BY, Vissers CB, Leach JK. Increased survival and function of mesenchymal stem cell spheroids entrapped in instructive alginate hydrogels. Stem Cells Transl Med. 2016;5(6):773-81.

66. Lund AW, Stegemann JP, Plopper GE. Mesenchymal stem cells sense three dimensional type I collagen through discoidin domain receptor 1. Open Stem Cell J. 2009;1:40-53.

67. Yamaguchi Y, Ohno J, Sato A, Kido H, Fukushima T. Mesenchymal stem cell spheroids exhibit enhanced in-vitro and in-vivo osteoregenerative potential. BMC Biotechnol. 2014:14:105.

68. Favi PM, Benson RS, Neilsen NR, Hammonds RL, Bates CC, Stephens CP, Dhar MS. Cell proliferation, viability, and in vitro differentiation of equine mesenchymal stem cells seeded on bacterial cellulose hydrogel scaffolds. Mater Sci Eng C Mater Biol Appl. 2013;33(4):1935-44.

69. Cochis A, Grad S, Stoddart MJ, Fare S, Altomare L, Azzimonti B, Alini M, Rimondini L. Bioreactor mechanically guided 3D mesenchymal stem cell chondrogenesis using a biocompatible novel thermo-reversible methylcellulose-based hydrogel. Sci Rep. 2017;7:45018.

70. Azoidis I, Metcalfe J, Reynolds J, Keeton S, Hakki SS, Sheard J, Widera D. Three-dimensional cell culture of human mesenchymal stem cells in nanofibrillar cellulose hydrogels. MRS Communications. 2017;7(3):458-65.

71. Sheard JJ, Bicer M, Meng Y, Frigo A, Aguilar RM, Vallance TM, landolo D, Widera D. Optically transparent anionic nanofibrillar cellulose is cytocompatible with human adipose tissue-derived stem cells and allows simple imaging in 3D. Stem Cells Int. 2019;2019:3106929.

72. Edmondson R, Broglie JJ, Adcock AF, Yang L. Three-dimensional cell culture systems and their applications in drug discovery and cell-based biosensors. Assay Drug Dev Technol. 2014;12(4):207-18. 
73. Mirbagheri M, Adibnia V, Hughes BR, Waldman SD, Banquy X, Hwang DK. Advanced cell culture platforms: a growing quest for emulating natural tissues. Materials Horizons. 2019;6(1):45-71.

74. Hauser S, Widera D, Qunneis F, Muller J, Zander C, Greiner J, Strauss C, Luningschror $\mathrm{P}$, Heimann $\mathrm{P}$, Schwarze $\mathrm{H}$, et al. Isolation of novel multipotent neural crest-derived stem cells from adult human inferior turbinate. Stem Cells Dev. 2012;21(5):742-56.

75. Lee JH, Han YS, Lee SH. Long-duration three-dimensional spheroid culture promotes angiogenic activities of adipose-derived mesenchymal stem cells. Biomol Ther (Seoul). 2016;24(3):260-7.

76. Zhao G, Liu F, Lan S, Li P, Wang L, Kou J, Qi X, Fan R, Hao D, Wu C, et al. Large-scale expansion of Wharton's jelly-derived mesenchymal stem cells on gelatin microbeads, with retention of self-renewal and multipotency characteristics and the capacity for enhancing skin wound healing. Stem Cell Res Ther. 2015;6:38.

77. Domnina A, Novikova P, Obidina J, Fridlyanskaya I, Alekseenko L, Kozhukharova I, Lyublinskaya O, Zenin V, Nikolsky N. Human mesenchymal stem cells in spheroids improve fertility in model animals with damaged endometrium. Stem Cell Res Ther. 2018;9(1):50.

78. Sun Y, Wang Y, Zhou L, Zou Y, Huang G, Gao G, Ting S, Lei X, Ding X. Spheroid-cultured human umbilical cord-derived mesenchymal stem cells attenuate hepatic ischemia-reperfusion injury in rats. Sci Rep. 2018;8(1):2518.

79. Baraniak PR, McDevitt TC. Scaffold-free culture of mesenchymal stem cell spheroids in suspension preserves multilineage potential. Cell Tissue Res. 2012;347(3):701-11.

80. Tsai AC, Liu Y, Yuan X, Ma T. Compaction, fusion, and functional activation of three-dimensional human mesenchymal stem cell aggregate. Tissue Eng Part A. 2015:21(9-10):1705-19.

81. Lo YP, Liu YS, Rimando MG, Ho JH, Lin KH, Lee OK. Three-dimensional spherical spatial boundary conditions differentially regulate osteogenic differentiation of mesenchymal stromal cells. Sci Rep. 2016;6:21253.

82. Han S, Zhao Y, Xiao Z, Han J, Chen B, Chen L, Dai J. The three-dimensional collagen scaffold improves the stemness of rat bone marrow mesenchymal stem cells. J Genet Genomics. 2012;39(12):633-41.

83. Rampichová M, Chvojka J, Buzgo M, Prosecka E, Mikes P, Vyslouzilova L, Tvrdik D, Kochova P, Gregor T, Lukas D, et al. Elastic three-dimensional poly (epsilon-caprolactone) nanofibre scaffold enhances migration, proliferation and osteogenic differentiation of mesenchymal stem cells. Cell Prolif. 2013; 46(1):23-37.

84. Park H, Kim JS, Oh EJ, Kim TJ, Kim HM, Shim JH, Yoon WS, Huh JB, Moon SH, Kang SS, et al. Effects of three-dimensionally printed polycaprolactone/betatricalcium phosphate scaffold on osteogenic differentiation of adipose tissue- and bone marrow-derived stem cells. Arch Craniofac Surg. 2018; 19(3):181-9.

85. Brennan MA, Renaud A, Gamblin AL, D'Arros C, Nedellec S, Trichet V, Layrolle P. 3D cell culture and osteogenic differentiation of human bone marrow stromal cells plated onto jet-sprayed or electrospun micro-fiber scaffolds. Biomed Mater. 2015;10(4):045019.

86. Persson M, Lehenkari PP, Berglin L, Turunen S, Finnila MAJ, Risteli J, Skrifvars M, Tuukkanen J. Osteogenic differentiation of human mesenchymal stem cells in a 3D woven scaffold. Sci Rep. 2018;8(1):10457.

87. Nguyen LT, Liao S, Chan CK, Ramakrishna S. Enhanced osteogenic differentiation with 3D electrospun nanofibrous scaffolds. Nanomedicine (Lond). 2012;7(10):1561-75

88. Yin Q, Xu N, Xu D, Dong M, Shi X, Wang Y, Hao Z, Zhu S, Zhao D, Jin H, et al. Comparison of senescence-related changes between three- and twodimensional cultured adipose-derived mesenchymal stem cells. Stem Cell Res Ther. 2020;11(1):226

89. Sefcik LS, Neal RA, Kaszuba SN, Parker AM, Katz AJ, Ogle RC, Botchwey EA. Collagen nanofibres are a biomimetic substrate for the serum-free osteogenic differentiation of human adipose stem cells. J Tissue Eng Regen Med. 2008;2(4):210-20

90. Yu L, Wu Y, Liu J, Li B, Ma B, Li Y, Huang Z, He Y, Wang H, Wu Z, et al. 3D culture of bone marrow-derived mesenchymal stem cells (BMSCs) could improve bone regeneration in 3D-printed porous Ti6Al4V scaffolds. Stem Cells Int. 2018;2018:2074021.

91. Shekaran A, Sim E, Tan KY, Chan JK, Choolani M, Reuveny S, Oh S. Enhanced in vitro osteogenic differentiation of human fetal MSCs attached to 3D microcarriers versus harvested from 2D monolayers. BMC Biotechnol. 2015; 15:102.
92. Wang XF, Song Y, Liu YS, Sun YC, Wang YG, Wang Y, Lyu PJ. Osteogenic differentiation of three-dimensional bioprinted constructs consisting of human adipose-derived stem cells in vitro and in vivo. PLoS One. 2016; 11(6):e0157214

93. Cheng NC, Chen SY, Li JR, Young TH. Short-term spheroid formation enhances the regenerative capacity of adipose-derived stem cells by promoting stemness, angiogenesis, and chemotaxis. Stem Cells Transl Med. 2013;2(8):584-94.

94. Whitehead J, Zhang J, Harvestine JN, Kothambawala A, Liu GY, Leach JK. Tunneling nanotubes mediate the expression of senescence markers in mesenchymal stem/stromal cell spheroids. Stem Cells. 2020;38(1):80-9.

95. Denu RA, Nemcek S, Bloom DD, Goodrich AD, Kim J, Mosher DF, Hematti P. Fibroblasts and mesenchymal stromal/stem cells are phenotypically indistinguishable. Acta Haematol. 2016;136(2):85-97.

96. Younis LT, Abu Hassan Ml, Taiyeb Ali TB, Bustami TJ. 3D TECA hydrogel reduces cellular senescence and enhances fibroblasts migration in wound healing. Asian J Pharm Sci. 2018;13(4):317-25.

97. Domnina A, Ivanova J, Alekseenko L, Kozhukharova I, Borodkina A, Pugovkina N, Smirnova I, Lyublinskaya O, Fridlyanskaya I, Nikolsky N. Threedimensional compaction switches stress response programs and enhances therapeutic efficacy of endometrial mesenchymal stem/stromal cells. Front Cell Dev Biol. 2020;8:473.

98. Burand AJ Jr, Di L, Boland LK, Boyt DT, Schrodt MV, Santillan DA, Ankrum JA. Aggregation of human mesenchymal stromal cells eliminates their ability to suppress human T cells. Front Immunol. 2020;11:143.

99. Frith JE, Thomson B, Genever PG. Dynamic three-dimensional culture methods enhance mesenchymal stem cell properties and increase therapeutic potential. Tissue Eng Part C Methods. 2010;16(4):735-49.

100. Follin B, Juhl M, Cohen S, Pedersen AE, Kastrup J, Ekblond A. Increased paracrine immunomodulatory potential of mesenchymal stromal cells in three-dimensional culture. Tissue Eng Part B Rev. 2016;22(4):322-9.

101. Bartosh TJ, Ylostalo JH, Bazhanov N, Kuhlman J, Prockop DJ. Dynamic compaction of human mesenchymal stem/precursor cells into spheres selfactivates caspase-dependent IL1 signaling to enhance secretion of modulators of inflammation and immunity (PGE2, TSG6, and STC1). Stem Cells. 2013;31(11):2443-56.

102. Ylostalo JH, Bartosh TJ, Coble K, Prockop DJ. Human mesenchymal stem/ stromal cells cultured as spheroids are self-activated to produce prostaglandin E2 that directs stimulated macrophages into an antiinflammatory phenotype. Stem Cells. 2012;30(10):2283-96.

103. Chierchia A, Chirico N, Boeri L, Raimondi I, Riva GA, Raimondi MT, Tunesi M, Giordano C, Forloni G, Albani D. Secretome released from hydrogelembedded adipose mesenchymal stem cells protects against the Parkinson's disease related toxin 6-hydroxydopamine. Eur J Pharm Biopharm. 2017:121:113-20.

104. Kim JH, Park IS, Park Y, Jung Y, Kim SH, Kim SH. Therapeutic angiogenesis of three-dimensionally cultured adipose-derived stem cells in rat infarcted hearts. Cytotherapy. 2013;15(5):542-56.

105. Young SA, Sherman SE, Cooper TT, Brown C, Anjum F, Hess DA, Flynn LE, Amsden BG. Mechanically resilient injectable scaffolds for intramuscular stem cell delivery and cytokine release. Biomaterials. 2018;159:146-60.

106. Carter K, Lee HJ, Na KS, Fernandes-Cunha GM, Blanco IJ, Djalilian A, Myung D. Characterizing the impact of $2 \mathrm{D}$ and $3 \mathrm{D}$ culture conditions on the therapeutic effects of human mesenchymal stem cell secretome on corneal wound healing in vitro and ex vivo. Acta Biomater. 2019;99:247-57.

107. Miranda JP, Camoes SP, Gaspar MM, Rodrigues JS, Carvalheiro M, Barcia RN, Cruz P, Cruz H, Simoes S, Santos JM. The secretome derived from 3Dcultured umbilical cord tissue MSCs counteracts manifestations typifying rheumatoid arthritis. Front Immunol. 2019;10:18.

108. Di Nicola M, Carlo-Stella C, Magni M, Milanesi M, Longoni PD, Matteucci P, Grisanti S, Gianni AM. Human bone marrow stromal cells suppress Tlymphocyte proliferation induced by cellular or nonspecific mitogenic stimuli. Blood. 2002;99(10):3838-43.

109. Polacek M, Bruun JA, Elvenes J, Figenschau Y, Martinez I. The secretory profiles of cultured human articular chondrocytes and mesenchymal stem cells: implications for autologous cell transplantation strategies. Cell Transplant. 2011;20(9):1381-93.

110. Qin Y, Wang L, Gao Z, Chen G, Zhang C. Bone marrow stromal/stem cellderived extracellular vesicles regulate osteoblast activity and differentiation in vitro and promote bone regeneration in vivo. Sci Rep. 2016;6:21961. 
111. Wang J, Ren H, Yuan X, Ma H, Shi X, Ding Y. Interleukin-10 secreted by mesenchymal stem cells attenuates acute liver failure through inhibiting pyroptosis. Hepatol Res. 2018;48(3):E194-202.

112. Yang H, Tian W, Wang S, Liu X, Wang Z, Hou L, Ge J, Zhang X, He Z, Wang $X$. TSG- 6 secreted by bone marrow mesenchymal stem cells attenuates intervertebral disc degeneration by inhibiting the TLR2/NF-kappaB signaling pathway. Lab Investig. 2018;98(6):755-72.

113. Xie L, Mao M, Zhou L, Zhang L, Jiang B. Signal factors secreted by $2 D$ and spheroid mesenchymal stem cells and by cocultures of mesenchymal stem cells derived microvesicles and retinal photoreceptor neurons. Stem Cells Int. 2017;2017:2730472

114. Yang C, Lim W, Park J, Park S, You S, Song G. Anti-inflammatory effects of mesenchymal stem cell-derived exosomal microRNA-146a-5p and microRNA-548e-5p on human trophoblast cells. Mol Hum Reprod. 2019; 25(11):755-71.

115. Costa MHG, McDevitt TC, Cabral JMS, da Silva CL, Ferreira FC. Tridimensional configurations of human mesenchymal stem/stromal cells to enhance cell paracrine potential towards wound healing processes. J Biotechnol. 2017; 262:28-39.

116. Krampera M, Glennie S, Dyson J, Scott D, Laylor R, Simpson E, Dazzi F. Bone marrow mesenchymal stem cells inhibit the response of naive and memory antigen-specific T cells to their cognate peptide. Blood. 2003;101(9):3722-9.

117. da Silva ML, Fontes AM, Covas DT, Caplan Al. Mechanisms involved in the therapeutic properties of mesenchymal stem cells. Cytokine Growth Factor Rev. 2009;20(5):419-27.

118. Park CW, Kim KS, Bae S, Son HK, Myung PK, Hong HJ, Kim H. Cytokine secretion profiling of human mesenchymal stem cells by antibody array. Int J Stem Cells. 2009;2(1):59-68.

119. Tachida Y, Suda K, Nagase H, Shimada K, Isono F, Kobayashi H. Secreted factors from adipose tissue-derived mesenchymal stem cells suppress oxygen/glucose deprivation-induced cardiomyocyte cell death via furin/ PCSK-like enzyme activity. Biochem Biophys Rep. 2016;7:266-72.

120. Moghaddam MM, Bonakdar S, Shariatpanahi MR, Shokrgozar MA, Faghihi S. The effect of physical cues on the stem cell differentiation. Curr Stem Cell Res Ther. 2019;14(3):268-77.

121. Engler AJ, Sen S, Sweeney HL, Discher DE. Matrix elasticity directs stem cell lineage specification. Cell. 2006;126(4):677-89.

122. Gilbert PM, Havenstrite KL, Magnusson KE, Sacco A, Leonardi NA, Kraft P, Nguyen NK, Thrun S, Lutolf MP, Blau HM. Substrate elasticity regulates skeletal muscle stem cell self-renewal in culture. Science. 2010;329(5995): $1078-81$.

123. Schellenberg A, Joussen S, Moser $K$, Hampe $N$, Hersch N, Hemeda H, Schnitker J, Denecke B, Lin Q, Pallua N, et al. Matrix elasticity, replicative senescence and DNA methylation patterns of mesenchymal stem cells. Biomaterials. 2014:35(24):6351-8.

124. Schurmann M, Wolff A, Widera D, Hauser S, Heimann P, Hutten A, Kaltschmidt C, Kaltschmidt B. Interaction of adult human neural crestderived stem cells with a nanoporous titanium surface is sufficient to induce their osteogenic differentiation. Stem Cell Res. 2014;13(1):98-110.

125. Vordemvenne T, Wahnert D, Koettnitz J, Merten M, Fokin N, Becker A, Buker $B$, Vogel $A$, Kronenberg $D$, Stange $R$ et al: Bone regeneration: a novel osteoinductive function of spongostan by the interplay between its nanoand microtopography. Cells 2020, 9(3):654. https://doi.org/10.3390/ cells9030654.

126. Greiner JF, Gottschalk M, Fokin N, Buker B, Kaltschmidt BP, Dreyer A Vordemvenne T, Kaltschmidt C, Hutten A, Kaltschmidt B. Natural and synthetic nanopores directing osteogenic differentiation of human stem cells. Nanomedicine. 2019:17:319-28.

127. Gauthier O, Bouler JM, Aguado E, Pilet P, Daculsi G. Macroporous biphasic calcium phosphate ceramics: influence of macropore diameter and macroporosity percentage on bone ingrowth. Biomaterials. 1998;19(1-3): 133-9.

128. Greiner JF, Hauser S, Widera D, Muller J, Qunneis F, Zander C, Martin I, Mallah J, Schuetzmann D, Prante C, et al. Efficient animal-serum free 3D cultivation method for adult human neural crest-derived stem cell therapeutics. Eur Cell Mater. 2011;22:403-19.

129. Seib FP, Prewitz M, Werner C, Bornhauser M. Matrix elasticity regulates the secretory profile of human bone marrow-derived multipotent mesenchymal stromal cells (MSCs). Biochem Biophys Res Commun. 2009;389(4):663-7.

130. Li L, Zhang Y, Mu J, Chen J, Zhang C, Cao H, Gao J. Transplantation of human mesenchymal stem-cell-derived exosomes immobilized in an adhesive hydrogel for effective treatment of spinal cord injury. Nano Lett. 2020:20(6):4298-305.

131. Han C, Zhou J, Liang C, Liu B, Pan X, Zhang Y, Wang Y, Yan B, Xie W, Liu F, et al. Human umbilical cord mesenchymal stem cell derived exosomes encapsulated in functional peptide hydrogels promote cardiac repair. Biomater Sci. 2019;7(7):2920-33.

132. Shafei S, Khanmohammadi M, Heidari R, Ghanbari H, Taghdiri Nooshabadi V, Farzamfar S, Akbariqomi M, Sanikhani NS, Absalan M, Tavoosidana G. Exosome loaded alginate hydrogel promotes tissue regeneration in fullthickness skin wounds: an in vivo study. J Biomed Mater Res A. 2020;108(3): $545-56$

133. Zavala G, Ramos MP, Figueroa-Valdes Al, Cisternas P, Wyneken U, Hernandez M, Toa P, Salmons B, Dangerfield J, Gunzburg WH, et al. Semipermeable cellulose beads allow selective and continuous release of small extracellular vesicles (sEV) from encapsulated cells. Front Pharmacol. 2020;11:679.

134. Qu H, Fu H, Han Z, Sun Y. Biomaterials for bone tissue engineering scaffolds: a review. RSC Adv. 2019:9(45):26252-62.

135. Hardy JG, Sukhavasi RC, Aguilar D, Villancio-Wolter MK, Mouser DJ, Geissler SA, Nguy L, Chow JK, Kaplan DL, Schmidt CE. Electrical stimulation of human mesenchymal stem cells on biomineralized conducting polymers enhances their differentiation towards osteogenic outcomes. J Mater Chem B. 2015:3(41):8059-64.

\section{Publisher's Note}

Springer Nature remains neutral with regard to jurisdictional claims in published maps and institutional affiliations. 